\title{
UPAYA POLISI AIRUD DALAM PENANGGULANGAN TERJADINYA TINDAK PIDANA ILLEGAL FISHING DI WILAYAH PERAIRAN TANJUNGBALAI
}

\author{
Oleh: \\ Lamhot Gurning ${ }^{1)}$, \\ Mangasa Manurung ${ }^{2)}$, \\ dan H. Bachtiar Simatupang ${ }^{3)}$ \\ Universitas Darma Agung, Medan. ${ }^{1,2,3)}$ \\ E-Mail: \\ lamhotgurning@yahoo.com ${ }^{1}$, \\ manurungmangasa@gmail.com ${ }^{2)}$, \\ dan simatupang.bachtiar167@yahoo.co.id ${ }^{3)}$
}

\begin{abstract}
Illegal fishing is an act that is very detrimental to a nation and state. The impact will be seen in the short and long term. The government makes handling illegal fishing crimes a very serious concern. This study aims at determining the forms of illegal fishing, AIRUD Police efforts in overcoming and knowing the inhibiting factors of illegal fishing in Tanjungbalai waters. Descriptive analytical research means trying to collect, study, analyze, and describe the illegal fishing countermeasures. The results showed the forms of illegal fishing in Tanjungbalai, namely the use of fishing gear that is in conflict with the laws and regulations (trawl pull). The efforts of AIRUD Police in tackling the occurrence of illegal fishing in the waters of Tanjungbalai are preventive and repressive efforts. Preventive efforts aimed at increasing the intensity of the socialization of laws and regulations to the public, and increasing patrols in waters according to the scope of duties of the Air Force Police Tanjungbalai. Refressive efforts, namely describing decisive action against illegal fishing perpetrators so that it provides a deterrent effect and then provides direction so as not to do the same thing over and over again. The obstacles of AIRUD Police in tackling illegal fishing are the lack of personnel, and the fishermen's HR which are still relatively low, the completeness of facilities and supporting facilities that are still limited in increasing routine patrols in carrying out the tasks of supervision, protection and protecting the special community of fishermen in the waters.
\end{abstract}

Keywords: Illegal Fishing, AIRUD Police, Tanjungbalai.

\begin{abstract}
ABSTRAK
Illegal fishing merupakan suatu tindakan yang sangat merugikan bagi suatu bangsa dan negara. Dampak yang ditimbulkan akan terlihat pada jangka pendek dan jangka panjang. Pemerintah menjadikan penanganan kejahatan illegal fishing menjadi perhatian yang sangat serius. Penelitian ini bertujuan untuk mengetahui bentuk-bentuk illegal fishing, upaya Polisi AIRUD dalam penanggulangan dan mengetahui faktor-faktor penghambat penanggulangan illegal fishing di wilayah perairan Tanjungbalai. Penelitian bersifat deskriptif analisis artinya berusaha mengumpulkan, mengkaji, menganalisis, serta mendeskripsikan tentang penanggulangan illegal fishing. Hasil penelitian menunjukkan bentuk-bentuk illegal fishing di Tanjungbalai yaitu penggunaan alat tangkap yang bertentangan dengan peraturan perundang-undangan (pukat tarik). Upaya Polisi AIRUD dalam penanggulangan terjadinya illegal fishing diperairan Tanjungbalai yaitu upaya prefentif dan refresif. Upaya preventif yang dimaksudkan meningkatkan intensitas sosialisasi peraturan perundang-undangan kepada masyarakat, dan peningkatan patroli diperairan sesuai dengan jangkauan tugas Polisi AIRUD Tanjungbalai. Upaya refresif yaitu memerikan tindakan tegas terhadap pelaku illegal fishing sehingga memberikan efek jera dan selanjutnya memberikan arahan agar tidak melakukan hal yang sama
\end{abstract}


secara berulang-ulang. Hambatan Polisi AIRUD dalam penangulangan illegal fishing yaitu kurangnya personil, dan SDM nelayan yang masih terbilang rendah, kelengkapan sarana dan fasilitas pendukung yang masih terbatas dalam meningkatkan patroli rutin dalam melaksanakan tugas pengawasan, perlindungan dan pengayom masyarakan khsusunya nelayan di perairan.

Kata Kunci: Illegal Fishing, Polisi AIRUD, Tanjungbalai.

\section{PENDAHULUAN}

Letak negara Indonesia yang strategis dimana terletak di antara benua Asia dan Australia dan dua samudra (Hindia dan Pasifik) sangat mendukung potensi sumber daya alam darat dan laut yang melimpah. Disamping itu, Indonesia merupakan negara kepulauan dengan garis pantai terpanjang dan terluas di dunia. Total laut Indonesia dua pertiga dari luas negara Indonesia dengan total laut 5,9 juta $\mathrm{Km} 2$ (75\%) yang terdiri dari 3,2 juta $\mathrm{Km} 2$ laut territorial dan 2,7 Km2 laut Zona Ekonomi Eksklusif (ZEE) Indonesia (Lasabuda dan Ridwan, 2013) . Kondisi potensi yang melimpah membuat laut Indonesia khususnya sumber daya ikan sangat potensial untuk dikelolah. Pengelolahan potensi dapat dimungkinkan secara legal maupun illegal (Muhamad, 2012).

Pengelolaan secara legal berarti mendapat izin yang resmi dan sesuai dari pemerintah, akan tetapi pengelolaan secara illegal sangat merugikan negara Indonesia. Pengelolaan sumber daya laut dalam eksplorasi ikan secara tidak sah sering disebut dengan istilah illegal fishing (Hehanussa dkk., 2018). Illegal fishing merupakan kegiatan yang dilaksanakan dan bertentangan dengan ketentuan peraturan perundang-undangan di bidang perikanan yang berlaku dalam suatu negara (Kementerian Kelautan dan Perikanan RI, 2017; Hehanussa dkk., 2018). Berdasarkan tindak pidana illegal fishing yang dilakukan antara lain penggunaan bahan peledak, penggunaan alat tangkap modifikasi, surat ijin yang tidak sah (illegal) dan penangkapan ikan dengan melanggar daerah penangkapan (sidhing ground) (Mahmudah dan Nunung, 2015). Kegiatan illegal fishing yang dilakukan sangat merugikan dan bertentangan dengan perundang-undangan yang berlaku di negara Indonesia. Undang-undang yang mengatur tentang pemanfaatan dan eksplorasi hasil laut dalam pengaturan dan pencegahan antara lain Undang-Undang Republik Indonesia Nomor 45 Tahun 2009, Undang-Undang RI No. 5 Tahun 1983 tentang Zona Ekonomi Eksklusif (ZEE) Indonesia, Undang-Undang RI nomor 17 Tahun 2008 tentang Pelayaran Perubahan Undang- Undang RI Nomor 21 Tahun 1992, Undang- Undang RI Nomor 32 Tahun 2014 tentang Kelautan, dan Undang-Undang RI Nomor 45 tahun 2009 tentang Perikanan. Kesemua perundangundangan yang ada dengan jelas telah mengatur semua sistem regulasi yang akan dialakukan oleh suatu orang atau badan usaha yang ingin melakukan kegiatan ekplorasi sumberdaya alam alaut terkhusus dalam eksplorasi ikan di laut Indonesia. Kegiatan illegal fishing sangat berdampak buruk pada suatu negara. Dampak buruk yang ditimbulkan antara lain kegiatan illegal fishing merusak kelestarian dan keberlanjutan ekosistem laut, merugigan ekonomi negara, mengganggu stabilitas politik, dan dampak sosial. Salah satu potensi laut dengan sumber ikan yang melimpah di pesisir pantai timur laut Sumatera Utara, Indonesia adalah Tangjungbalai. Secara astronomis Tanjungbalai berada pada 2058'15" 3o01'32" LU dan 99o48'00" - 99o50'16" BT, merupakan daerah pertemuan sungai Silau dan sungai Asahan yang bermuara ke selat Malaka. Posisi geografis Tanjungbalai relatif dekat dengan Malaysia, Singapura dan Thailand (Pemerintah Tangjungbalai, 2015,). Potensi sumberdaya ikan yang melimpah ini membuat pelabuahan Tangjungbalai menjadi pemasok ikan terbesar di Sumatera Utara kedua setelah pelabuahan Belawan. Berdasarkan hal tersebut membuat peneliti tertarik untuk melakukan penelitian tinjauan dan bagaimana upaya penanggulangan illegal fishing yang dilakukan oleh Polisi AIRUD Tangjungbalai. 


\section{TINJAUAN PUSTAKA}

\section{Kerangka Teori}

Teori kedaulatan negara ini dikemukanan oleh Jellineck (Jerman), Paul Laband (Jerman) dan Hans Kelsen (Austria) pada abad ke -19 yang menyatakan bahwa: (a) Hukum adalah kehendak negara. Hukum bukan kemauan bersama anggota masyarakat dan negara mempunyai kekuatan tak terbatas; dan (b) Hukum ditaati orang karena negara menghendakinya. Istilah kedaulatan negara sering digunakan untuk merujuk pada pengertian "kekuasaaan tertinggi yang dimiliki oleh suatu pemerintah negara" yang memiliki makna sebagai kewenangan politik paripurna (tertinggi) untuk mengatur dan menentukan jatidirinya dan otoritas lainnya (Sigit, 2014). Teori Kedaulatan Hukum muncul pada abad ke20 dan menentang teori Kedaulatan Negara. Tokoh-tokohnya adalah Cruot (Perancis), Duguit (Perancis), dan Krabbe (Belanda). Teori ini berpendapat bahwa: (1) Hukum berasal dari perasaan hukum yang ada pada sebagian besar anggota masyarakat; dan (2) Hukum mewujudkan perasaan hukum sebagian besar anggota masyarakat; Oleh karenanya hukum ditaati oleh anggota masyarakat (Gunawan, 2012).

Secara konsepsional bahwa penegakan hukum terletak pada keselarasan nilai-nilai yang terjabarkan dalam kaidah-kaidah baik dan sebagai penjabaran nilai untuk mempertahankan kedamaian dalam hidup (Koho, 2015). Tataran teoritis penegakan hukum bukan hanya memberikan sanksi kepada orang atau badan hukum yang melakukan pelanggaran, tetapi juga perlu dipahami sebagai penegakan hukum yang bersifat preventif (Supriadi dan Alimudin, 2001). Lawrece M. Friedman (2013) mengemukakan penegakan hukum yang efektif dan berhasil sangat tergantung pada tiga aspek sistem hukum antara lain sebagai berikut:
a. Substansi Hukum (Substance of the
Law)
b. Struktur Hukum (Structure of Law)
c. Budaya Hukum (Legal Culture)

\section{Kerangka Konseptual}

Penelitian ini memuat kerangka konseptual yang digunakan sebagai pendekatan pemecahan masalah. Kerangka penelitian ini merupakan pendekatan yang menggunakan pendekatan ilmiah dalam mengumpulkan dan menganalisis masalah serta kasus yang diangkat dalam penelitian ini. Adapun kerangka berpikir dalam penelitian ini dimulai dari studi pendahuluan kemudian dikumpulkan kasus illegal fishing, penanganan kasus illegal fishing, tindak pidana yang diperbuat dan hukum yang dijatuhkan kepada pelaku, dilanjutkan kepada identifikasi faktor-faktor penghambat dalam penanggulangan illegal fishing serta perumusan dan analisis pada upaya penanggulangan kejahatan pidana illegal fishing.

\section{METODE PELAKSANAAN}

\section{Lokasi Penelitian}

Penelitian ini dilakukan di Kota Tanjungbalai Provinsi Sumatera Utara dengan data utama yaitu kejadian illegal fishing yang ditangani oleh Polisi AIRUD Polres Tanjungbalai. Akan tetapi, tidak menutup kemungkinan dalam mengumpulkan dan membahas kasus kejahatan illegal fishing yang terjadi dari instansi-instansi yang memiliki kewenangan dalam penanganan dan penindakan kejahatan yang serupa.

\section{Jenis dan Sifat Penelitian}

Penelitian ini bersifat deskriptif analisis karena penelitian ini mengangkat kejadian- kejadian illegal fishing yang terjadi di perairan Tanjungbalai, faktorfaktor penyebab kejahatan illegal fishing, penegakan hukumnya dan upaya yang diterapkan oleh Polisi AIRUD dalam penanggulangan kejahatan illegal fishing dalam menekan kejahatan tersebut.

\section{Teknik Pengumpulan data}

Teknik pengumpulan data melalui survei, observasi dan wawancara langsung di lapangan. Data yang diperoleh meliputi data primer dan data sekunder. Data primer diperoleh dari responden secara langsung. Penentuan responden menggunakan purposive sampling dengan teknik wawancara terstruktur berdasarkan instrumen yang telah disusun peneliti dan 
alternatif jawaban telah dimuat dalam bentuk kuisioner (Moh Nazir, 1988). Salim dan Erlis (2013) mengemukakan data sekunder meliputi dokumen-dokumen dan studi literatur yang mendukung dilapangan yang dikumpulkan dari instansi-instansi terkai meliputi instansi Pol AIRUD (data utama), PSDKP, Karantina Ikan, KSDA Tanjungbalai. Studi literatur yang dimaksudkan pengumpulan data-data dari berbagai sumber bacaaan yang relevan seperti jurnal, buku dan media online dengan melakukan pemahaman, menganalisis setiap informasi yang diperoleh sehingga memiliki ketersambungan dengan masalah yang diteliti.dengan topik yang dikaji yaitu upaya Polisi AIRUD dalam penanggulangan illegal fishing.

\section{Teknik Analisis Data}

Teknik analisis data menggunakan metode kualitatif, dimana peneliti melakukan analisis hasil penelitian yang menghasilkan data deskriptif analitik sesuai dengan data dan hukum yang akan dipergunakan (Mukti dan Yulianto, 2010). Deskriptif analitik bertujuan untuk mengetahui jenis-jenis pelanggaran, jumlah pelanggar, dan subjek pelanggar. Data yang dikumpul ditabulasi lalu dianalisis dan hasil dari analisis disajikan dalam bentuk tematik berupa gambar, tabel atau grafik. Analisis deskriptif analitik terhadap data yang diperoleh menggunakan pendekatan kekuatan/Strength kelemahan/Weakness, peluang/opportunity, dan ancaman/Threat (SWOT). Pendekatan analisis data yang digunakan akan mengharapkan menemukan pilihan alternatif kebijakan strategis terbaik berdasarkan skala prioritas dalam penanganan kasus illegal fishing.

\section{HASIL dan PEMBAHASAN \\ a. Illegal Fishing}

Illegal fishing didefensikan merupakan suatu tindakan penangkapan ikan yang dilakukan tidak sesuai dengan peraturan perundang-undangan atau ketentuan- ketentuan yang berlaku disuatu negara tersebut dan merupakan tindakan yang tidak sah (illegal) yang berdampak pada kerugian negara yang dieksploitasi ikannya dan setiap pelaku yang melakukan kegiatan penangkapan ikan (illegal fishing) secara tidak sah akan mendapat hukuman sesuai dengan peraturan perundangundangan dan ketentuan yang berlaku di negara tersebut.

Widodo (2003) IUU fishing dalam kegiatan illegal fishing dikategorikan dalam tiga kelompok yaitu: a) Illegal fishing, kegiatan penangkapan yang tidak sah (1) dilakukan oleh kapal-kapal nasional atau asing di dalam perairan dibawah yurisdiksi suatu negara, tanpa ijin dari negara itu atau dalam keadaan melawan hukum dan regulasi negara tersebut; (2) dilakukan oleh kapal-kapal berbendera negara-negara anggota dari organisasi pengelola yang relevan tapi beroperasi melawan aturan-aturan konservasi dan pengelola sumberdaya yang diadopsi oleh negara tersebut, dimana negara-negara tersebut terikat atau melawan hukum internasional yang sedang dilaksanakan; atau keawajiban internasional termasuk yang bekerjasama dengan suatu organiasis pengelolaan yang relevan; b) Unreported fishing, mengacu pada kegiatan penangkapan termasuk (1) tidak melaporkan atau dilaporkan secara tidak benar (missreported) kepada otoritas nasional yang relevan, bertentangan dengan peraturan-peraturan dan perundangundangan; (2) dilakukan di dalam area dibawah kompetensi sebuah organisasi pengelolaan perikanan regional yang tidak dilaporkan atau dilaporkan secara tidak benar, bertentangan dengan prosedur pelaporan dari organisasi tersebut; dan c) Unregulated fishing megacu pada kegiatan penangkapan yakni (1) didalam area suatu organisasi pengelolaan perikanan regional yang dilakukan kapal tanpa nasionalitas, atau oleh kapal dengan berbendera suatu negara bukan anggota dari organisasi tersebut, atau oleh suatu fishing entry dengan cara yang tidak konsisten dengan atau melawan aturan konservasi dan pengelolaan dari organisasi tersebut dan (2) di area berbagai stok ikan yang berjkaitan dengan tinadanya aturan (tindakan) konservasi dan pengelolaan yang diaplikasikan dimana aktivitas penangkapan dilakukan dengan cara- cara yang tidak 
konsisten dengan tanggung jawab negara bagi konservasi atas sumber daya hayati kegiatan dibawah tanggungjawab hukum internasional.

Di Indonesia ada 12 modus operasi IUU fishing antara lain: 1. pemalsuan perijinan kapal; 2. double flagging \& double registered; 3. menangkap ikan tanpa izin/dokumen pelayaran (SLO dan SPB); 4. modifikasi kapal secara illegal (mark down, merubah call sign, mesin); 5. menggunakan nakhoda dan ABK asing; 6. tidak mengaktifkan transmitter pemantauan kapal (VMS dan AIS); 7. transshipment Ilegal; 8. pemalsuan data logbook; 9. pelanggaran jalur penangkapan ikan; 10. penggunaan alat tangkap yang dilarang; 11. tidak bermitra dengan unit pengolahan ikan; 12 . tidak mendaratkan ikan di pelabuhan yang ditetapkan dalam izin (Sistiyanto, 2018). Kegiatan illegal fishing berdasarkan tindak pidana dari kegiatan yang dilakukan antara lain sebagai berikut:

1. penggunaan bahan peledak; kegiatan illegal fishing dengan penggunaan bahan peledak (bom ikan) atau ilegal tetapi cara tersebut juga sangat merusak (destructive fishing).

2. Penggunaan alat tangkap modifikasi dan alat bantu penangkap ikan; penggunaan alat tangkap yang dimodifikasi oleh nelayan bertujuan untuk meningkatkan kuantitas hasil tangkapan ikan. Modifikasi alat tangkap yang dilakukan terkadang mengabaikan peraturan-peraturan yang telah ditentukan. Surat ijin yang tidak sah (illegal); penangkapan ikan dengan tidak melengkapi dan menyiapkan dokumen-dokumen perizinan yang tidak sesuai dengan ketentuan berarti melakukan kegiatan penangkapan ikan secara illegal.

3. Penangkapan ikan dengan melanggar daerah penangkapan (fishing ground); wilayah perairan Indonesia yang terdiri dari 11 (sebelas) zona perairan penangkapan yang tersebar di seluruh Indonesia, berdasarkan Peraturan Menteri Kelautan dan Perikanan No. 1 Tahun 2009 tentang Wilayah Pengelolaan Perikanan Republik Indonesia, bahwa Wilayah pengelolaan perikanan untuk penangkapan ikan meliputi Perairan Pedalaman, Perairan Kepulauan, Zona Teritorial, Zona Tambahan, dan Zona Ekonomi Eksklusif Indonesia (ZEEI).

b. Dasar-Dasar Hukum Yang Mengatur Illegal Fishing

Dasar hukum yang menjadi landasan hukum pengaturan illegal fishing di Indonesia adalah:

a. Undang-Undang Republik Indonesia Nomor 45 Tahun 2009.

b. Undang Undang RI Nomor 5 tahun 1983 tentang Zona Ekonomi Ekslusif Indonesia.

c. Undang-Undang RI Nomor 17 Tahun 2008 Tentang Pelayaran Perubahan Undang Undang RI Nomor 21 Tahun 1992 Tentang Pelayaran

d. Undang Undang RI Nomor 32 tahun 2014 Tentang Kelautan

e. Undang-Undang Republik Indonesia Nomor 45 tahun 2009 Tentang Perikanan

\section{c. Kerugian dari Kegiatan Illegal Fishing}

Kegiatan-kegiatan yang dilakukan tentu akan membawa dampak baik buruk maupun dampak negatif. Apalagi kegiatan tersebut bersifat tidak sah (illegal) tentu ini sangat membawa dampak negatif. Dampak yang ditimbulkan oleh kegiatan illegal fishing pada semua sektor kehidupan berbangsa dan bernegara. Dampak yang ditimbulkan antara lain:

a. Merusak kelestarian dan keberlanjutan ekosistem laut, kelestarian dan keberlanjutan ekosistem laut harus dijaga keberlangsungannya, karena kalua tidak dijaga maka sumberdaya laut itu akan rusak dan berujung pada kepunah.

b. Merugikan Ekonomi Negara, kerugian Indonesia akibat penangkapan ikan dengan ilegal cukup besar. Data Badan Pangan Dunia atau FAO mencatat kerugian Indonesia akibat illegal fishing Rp 30 triliun per tahun. Data itu dinilai Menteri Kelautan dan Perikanan Susi Pudjiastuti cukup kecil. Menurut hitung-hitungannya, akibat illegal fishing, kerugian negara bisa mencapai US\$ 
20 miliar atau Rp 240 triliun per tahun (Kompas, 2014).

c. Dampak Politik, illegal fishing juga berdampak pada hubungan politik, yang terlihat sebagai pemicu ketegangan hubungan diplomatik antara negara. Terutama mengganggu kedaulatan Negara Kesatuan Republik Indonesia (NKRI), sehingga menimbulkan citra negatif, karena beberapa negara menganggap bahwa Indonesia tidak mampu mengelola sumber daya kelautan dengan baik.

d. Dampak Sosial

e. Dampak Keberlanjutan Ekosistem

\section{e. Hambatan Penanggulangan Illegal Fishing}

\section{Kebijakan Penanganan Illegal Fishing}

Pengelolaan sumberdaya hasil laut khususnya ikan tidak hanya menjadi tanggung jawab satu negara saja, tetapi menjadi tanggung jawab seluruh elemen yang terlibat. Pengelolaan yang baik oleh satu negara tidak akan dapat menunjukan keberhasilan pengelolaan secara keseluruhan jika elemen- elemen lain tidak turut mengelola sumberdaya ini secara bijak. Penangkapan ikan merupakan sumberdaya bersama (common property), sudah tentu hal ini pun menuntut pengelola yang secara bersama pula, oleh karena itu kerjasama international dianggap sebagai solusi terbaik untuk dapat mengatasi masalah yang timbul. Kebijakan pemerintah dalam upaya merespon penindakan terhadap pelaku illegal fishing melalui instruksi Presiden RI dengan memerintahkan agar melakukan pengawasan lapangan dan menindak tegas, jika perlu dengan menenggelamkan kapal asing yang melakukan pencurian ikan di perairan Indonesia. Intrusksi Presiden ini sesuai dengan amanat UUD Negara RI sebagaimana dijabarkan dalam UU No31 Tahun 2004 tentang perikanan jo. UU No 45 tahun 2009 tentang Perubahan Atas UU No 31 Tahun 2004 tenatng Perikanan. Kebijakan ini bagian dari upaya keras Presiden kepada pelaku illegal fishing serta sebagai bentuk komitmen Indonesia dalam pengawasan dan penegakan hukum di perairan Indonesia (Haryanto dan Joko, 2017).

Alasan lain dalam kebijakan penindangkan tindak pidanan pelaku illegal fishing dengan penenggelaman kapal oleh pemerintah Indonesia yaitu:

(1) pelakasanaan pilar keempat dalam upaya mengujudkan visi indonesia sebagai poros maritim dunia

(2) upaya untuk menimbulkan efek jera atau efek gentar (shock therapy)

(3) pelaksanaan kebijakan kriminal berupa kebijakan pencegahan penanggulanagan kejahatan

(4) penegasan, perwujudtan dan pelaksanaan yuridiksi dan kedaulatan negara Indonesia

(5) upaya luar biasa pemberantasan illegal fishing sebagai kejahatan utama di perairan laut Indonesia (Haryanto dan Joko, 2017).

Kebijakan penenggelaman kapal berbendera asing yang melakukan kegiatan tindak pidanan pencurian ikan berpedoman pad ketentuan UU No 45 Tahun 2009 tentang Perubahan Atas UU No 31 Tahun 2004 tentang perikanan pada Pasal 69 ayat (1) jo. Pasal 76A dan ayat (4) jo. UU No 8 Tahun 1981 (KUHAP), Pasal 38 jo. Pasal 45 dan Pasal 38. Lingkup Internasional telah terdapat organisasi atau lembaga internasional yang mengatur hal-hal yang terkait dengan perikanan termasuk perikanan tangkap, dimana organisasi tersebut menetapkan dan membuat kebijakan - kebijakan yang terkait dengan upaya pemanfaatan, pengelolaan dan konvensi dari internasional yang disepakati bersama. Konvensi internasional adalah suatu perjanjian yang mengikat negara-negara yang menjadi pesertanya setelah mulai prosesratifikasi (Departemen Kelautan dan Perikanan-DKP, 2003). Organisasi Internasional yang berperan dalam hal ini adalah FAO (Fisheries and Agriculture Organization). Dasar hukum dalam dalam pembentukan organisasi regional ini adalah pasal 64 ayat 1 tentang Konvensi Hukum Laut 
1982 yang mewajibkan kerjasama antar negara melalui organisasi internasional. di kawasan laut dimana tidak terdapat organisasi perikanan demikian, maka negara-negara yang terlibat wajib bekerjasama untuk mendirikan organisasi dan berperan serat didalamnya. UNCLOS 1982 sebagai negara yang berdaulat dalam penerapan yurisdiksi criminal illegal fishing kebijakan penenggelaman kapal asing pelaku tindak pidana berdasarkan prinsip teritorial dan penerapan yurisdiksi kriminal berdasarkan prinsip ekstrateritorial.

\section{a. Faktor Penyebab Terjadinya Illegal Fishing}

Faktor-faktor penyebab Illegal fishing di perairan Indonesia secara langsung maupun tidak langsung menurut Kementerian Kelautan dan Perikanan Indonesia sangat sulit diatasi, karena dipengaruhi (1) Span of control yang sangat luas; (2) Keterbatasan armada armada pengawasan laut Indonesia; (3) Sistem Law enforcement masih lemah; (4) Lemahnya peraturan mengenai pengawasan kapal asing di perairan Indonesia; (5) Lemahnya kemampuan sumber daya nelayan (Tanty, 2019).

\section{b. Jenis-Jenis Illegal Fishing Yang Terjadi Di Tanjungbalai}

Jenis-jenis illegal fishing antara lain yaitu penggunaan bahan kimia dan alat berbahaya yang tidak ramah lingkungan. Beberapa tindakan serius yang telah direrapkan terhadap pelanggaran seperti penipuan, pemalsuan, perdagangan manusia, dan penghindaran pajak (Ana, 2019). Jenis illegal fishing yang terjadi yaitu alat penangkap ikan skala besar (Pukat Harimau dan Trawl). Alat tangkap tersebut sudah dilarang untuk digunakan karena tidak sesuai dengan ketentuan dan keadaan kelautan. Hasil pengawasan KKP selama 2010- 2016 menyebutkan bahwa praktek illegal fishing oleh KIA sebagian besar terjadi di Zone Exlusive Economic (ZEE) dan banyak juga terjadi di perairan kepulauan (archipelagic state). Pada umumnya, Jenis alat tangkap yang digunakan oleh KIA atau kapal eks Asing illegal di perairan Indonesia adalah alat-alat tangkap produktif seperti purse seine dan pukat (trawl). Kegiatan illegal fishing juga dilakukan oleh kapal ikan Indonesia (KII). Berdasarkan data terkait tindak pidana kelautan dan perikanan selama tahun 2016, dalam setahun sebanyak 243 kasus tindak pidana kelautan dan perikanan telah terjadi. Dari 243 kasus tindak pidana kelautan dan perikanan tersebut, 218 kasus diantaranya adalah kasus tindak pidana perikanan, khususnya illegal fishing.

Modus operandi illegal fishing menurut laporan KKP dilakukan dengan beragam cara antara lain; melakukan penangkapan ikan tanpa izin Surat Izin Usaha Perikanan (SIUP) dan Surat Izin Penangkapan Ikan (SIPI) maupun Surat Izin Kapal Pengangkutan Ikan (SIKPI), mengunakan izin palsu, menggunakan alat tangkap yang dilarang, menangkap jenis ikan (spesies) yang tidak sesuai dengan izin, menangkap ikan di wilayah yang tidak sesuai ijin, tidak melaporkan hasil tangkapan yang sesungguhnya atau pemalsuan data hasil tangkapan, membawa ikan hasil tangkapan langsung ke negara lain (transhipment), penangkapan ikan di wilayah yang dilarang, menangkap ikan di wilayah kompetensi RFMOs tanpa mengindahkan ketentuan RFMOs maupun ketentuan internasional, penangkapan ikan menggunakan modifikasi API/ABPI ikan, pemalsuan dokumen perijinan (dokumen pengadaan, registrasi, dan perizinan kapal), menggunakan identitas ganda atau double flag, melibatkan aparat dan pengusaha lokal, tidak mengaktifkan transmitter (khusus bagi kapal- kapal yang diwajibkan memasang transmitter), dan berbagai modus lainnya yang dilarang (Haryanto dan Joko, 2017).

Kasus Illegal fishing yang terjadi di perairan Tanjungbalai yang ditangani oleh Polisi AIRUD dari tahun 2015 s/d 
2018 terdapat dua kasus. Kasus pertama yang ditangani pada tahun 2016 dan kasus kedua pada tahun 2018. Jenis tindakan illegal fishingyang dilakukan yaitu menggunakan alat tangkap yang dilarang dalam peraturan perundangundangan nomor 45 tahun 2009 perubahan atas undang-undangn nomor 31 tahun 2004 tentang perikanan dimana menggunakan alat tangkap pukat tarik. Alat tangkap Pukat Tarik ini merupakan alat tangkap yang menangkap hasil tangkap yang sangat banyak. Hasil tangkapan yang diperoleh juga sangat beranekaragama. Keuntungan menggunakan alat tangkapan tersebut cenderung mudah digunakan/dioperasikan dan mendapatkan hasil tangkapan ikan yang berlimpah. Penggunaan alat tangkap jenis pukat Tarik ini merupakan jenis alat tangkap yang dapat dipergunakan secara berulangulang. Pelaksanaan penindakan pelaku illegal fishing sesuai mekanisme ketentuan Pasal 76A UU Nomor 45 Tahun 2009 atas perubahan UU No 31 Tahun 2004 tentang Perikanan jo Pasal 38 jo Pasal 45 UU No 8 Tahun 1981 (KUHAP). Mekanisme mengatur dalam melakukan penyitaan atas benda/alat yang digunakan dalam melakukan tindak pidana illegal fishing dimusnakan setelah mendapatkan persetujuan Ketua Pengadilan Negeri dan mendapatkan putusan hukum yang tetap (inkracht) sebagaimana diatur dalam KUHAP. Hal ini juga diperkuat dengan Surat Edaran Mahkama Agung Nomor 01/Bua.6/HS/SP/III/2015.

Pelaku tindak pidana dari kasus illegal fishing tersebut telah berhasil diselidiki oleh Satuan Polisi Perairan (POLISI AIRUD) Tanjungbalai dan dilimpahkan ke pengadilan untuk diadili dan mendapatkan putusan dari majelis hakim mengacu pada Pasal 76A UU Nomor 45 Tahun 2009 atas perubahan UU No 31 Tahun 2004 tentang Perikanan jo Pasal 38 jo Pasal
45 UU No 8 Tahun 1981 (KUHAP). Dari hasil putusan peradilan bahwa terdakwa terbukti bersalah melakukan tidnak pidana dengan "sengaja memiliki, menguasai, membawa atau menggunakan alat penangkap ikan dan/atau alat bantu penangkap ikan yang menggangu dan merusak keberlanjutan sumberdaya ikan. Menjatuhkan pidanan terhadap terdakwa oleh karena itu dengan pidanan penjara selama delapan bulan dengan denda sebesar Rp. 700.000.000,- (tujuh ratus juta rupiah) dengan ketentuan apabila denda tidak dibayarkan akan diganti dengan pidana kurangan badan selama 1 (satu) bulan. Kasus kedua pada prinsipnya sama dengan kasus pertama yang ditangani oleh Polisi. Tindak pidana yang dilakukan yaitu melakukan pelanggaran penggunaan alat tangkap yang dilarang atau tidak sesuai dengan peraturan perundang-undangan yang berlaku. Sanksi yang diterapkan untuk setiap pelanggaran adalah dengan aturan yang sesuai perundangundangan hukum pidana yang jelas Silalahi, R (2019).

\section{c. Penegakan Hukum Illegal \\ Fishing Oleh Polisi AIRUD Tanjungbalai}

1. Fungsi dan Peranan

Satpolair Tanjungbalai berada dibawah komando Polres Tanjungbalai. Polisi memegang prinsip-prinsip peraturan dalam melaksanakan tugas : a) professional; b) procedural; c) akuntabel; d) Transparan; dan e) Nesesitas (Syahputra, 2012). Satpolair bertugas melaksanakan fungsi kepolisian perairan, yang meliputi patroli perairan, penegakan hukum di perairan, pembinaan masyarakat pantai dan perairan lainnya, serta SAR. Dalam melaksanakan tugas sebagaimana dimaksud pada Undang-Undang Nomor 23 Tahun 2010 ayat (2), Satpolair menyelenggarakan fungsi (Peraturan $\mathrm{Ka}$ POLRI, 2010):a) pelaksanaan patroli, pengawalan penegakan hukum di wilayah perairan, dan pembinaan masyarakat pantai di daerah hukum Polres;b) pemberian bantuan SAR 
di laut/perairan; dan pelaksanaan transportasi kepolisian di perairan; c) pemeliharaan dan perbaikan fasilitas serta sarana kapal di lingkungan Polres

\section{Faktor-Faktor Penghambat Penegakan Hukum}

Faktor-faktor penghambat atau kendala terhadap tindak pidana illegal fishing diantaranya:a) aparat Penegak Hukum; aparat penegak hukum baik dalam arti preventif maupun dalam arti represif dalam menangani kasus-kasus illegal fishing jumlahnya terbatas, kemampuannya juga masih terbatas. Saat ini aparat penegak hukum dalam hal ini Polisi AIRUD melaksanakan tugas-tugas preventif seperti pemantauan, pembinaan, peringatan. Hambatan yang dialami oleh Polisi AIRUD Tanjungbalai dalam upaya prepentif yaitu sulitya mengumpulkan nelayan untuk melakukan sosialisasi tentang peraturan perundang-undangan yang harus dipatuhi sehingga terhindar dari kegiatan illegal fishing. Hambatan berikutnya terlihat dari masih lemahnya sumber daya manusia dari nelayan dalam memahami dalam pembelian penggunaan alat tangkap yang sesuai dengan peraturan perundangundangan. Hal ini terlihat ketika pelaku tertangkap tangan melakukan kegiatan penangkapan ikan secara illegal, nelayan menyampaian bahwa mereka mendapat tawaran dalam memberikan alat tangkap yang relatif murah tetapi hasil tangkapan yang relativf banyak. Hal ini menunjukkan masih rendahnya tingkat pemahaman dalam penmbelian dan penggunaan alat tangkap yang sesuai dengan peraturan perundang-undangan. Peran dari penegak hukum dalam hal ini Polisi Perairan dituntun semakin gencar untuk melakukan sosialisasi perundang-undangangan dalam penggunaan alat tangkap ikan yang sesuai dengan peraturan perundang-undangan yang berlaku. Apabila terjadi kegiatan illegal fishing mereka yang melakukan maka perlu dilakukan penindakan, penyelidikan, penyilidikan, penyitaan serta pelimpahan berkas ke pengadilan untuk diproses lebih lanjut untuk mendapatkan kepastihan hukum atas pelanggaran yang dilakukan. Hal ini menunjukan aparat penegak hukum seperti penyidik, penuntut umum, dan hakim yang memahami peraturan atau ketentuan hukum yang berlaku. b) fasilitas dan Sarana; tujuan penegakan hukum akan tercapai apabila terdapat fasilitas dan sarana di wilayah perairan Tanjungbalai. Keterbatasan fasilitas dan sarana akan mempengaruhi keberhasilan penegakan hukum. Fasilitas dan sarana dibutuhkan untuk menangani kasus-kasus illegal fishing di wilayah perairan Indonesia dalam hal ini Tanjungbalai akan melibatkan berbagai perangkat teknologi canggih untuk kepentingan operasionalisasinya yang memerlikan tenaga ahli dan biaya perawatan yang cukup mahal; dan c) kesadaran masyarakat; terbatasnya kesadaran hukum masyarakat terhadap penangkapan ikan secara legal disebabkan karena keawaman masyarakat terhadap berbagai aspek. Dalam hal ini kesadaran masyarakat terhadap perairan dapat dibina dan ditingkatkan melalui usaha-usaha seperti penyuluhan, bimbingan, keteladanan, serta keterlibatan masyakarat dalam menanggulangi illegal fishing. Di wilayah perairan Tanjungbalai, patroli yang dilakukan sudah akan terus dimaksimalkan untuk menekan tindak kejahatan khsusunya dalam menenkan kasus illegal fishing.

3. Upaya Penanganan dan Penanggulangan Illegal Fishing 


\begin{abstract}
Kegiatan illegal fishing merupakan kegiatan yang melibatkan banyak komponen yang terlibat diantaranya masyarakat nelayan, pemerintah dan pelaku perikanan.
\end{abstract}

Penanganan kegiatan terjadinya illegal fishing harus diarahkan pada dua sisi yaitu penegakan pada sisi internal dan penegakan pada sisi eksternal. Penegakan pada sisi internal diarahkan pada penguatan dan penegakan perundangundangan, perizinan, kemampuan pengawasan, pembenahan sistem hukum dan peradilan perikanan, serta penguatan armada tangkap perikanan. Penegakan pada sisi eksternal lebih diarahkan pada penguatan dan pembentukan kerjasama dengan pelaku-pelaku penangkapan ikan agar beroperasi sesuai dengan aturan yang berlaku secara nasional dan internasional. Penegakan pada sisi internal ini sangat diperlukan sebagai payung hukum yang kuat dalam memnberikan penindakan hukum kepada pelaku-pelaku illegal fishing. Misalnya dalam pemberia ijin harus transparan dan dengan ketat, dengan kata lain setiap pelaku yang ingin melakukan penangkapan ikan harus memenuhi aturan yang berlaku dan diproses secara cermat dan ketat. Disamping itu, penguatan kemampuan pengawas juga harus didukung. Penguatan pengawasan yang dimaksudkan antara lain: membentuk dan memberlakukan sistem Monitoring, Control, and Surveillance (MCS) salah satu dari sistem ini yang dipergunakan secara internasional FAO yaitu dengan menggunakan Vessel Monitoring Sistem (VMS). Sistem ini secara sederhananya menerapkan sistem berbasis data pad sistem informasi geografis sehingga VMS dapat memantau seluruh posisi kapal di wilayah perairan tertentu. Sehingga dengan demikian bisa terpantai kapal-kapal yang melakukan penangkapan ikan apakah sudah sesuai dengan aturan atau tidak. Hal ini juga memudahkan pengawasan jika terjadi penangkapan ikan yang dilakukan oleh kapal-kapal ikan yang berasal dari dalam maupun luar negeri. Penguatan armada dan moderenisasi armada juga perlu dilakukan inovasi guna memperkuat sistem monitoring dan pengawasan di perairan, karna tanpa moderenisasi armada maka kita akan ketinggalan dan selalu akan mengalami kegagalan dalam melakukan pengawasan dan penindakan kepada pelaku-pelaku penangkapan ikan yang tidak sesuai dengan aturan yang berlaku (illegal fishing).

Penguatan sistem peradilan hukum juga tidak kalah penting. Penguatan sistem peradilan hukum ini diperlukan untuk memberikan penindakan dan sanksi hukum yang mampu memberikan efek jerah pada pelaku-pelaku penangkapan perikanan yang tidak sesuai dengan aturan perundang-undangan yang berlaku (pemberian sanksi tegas pada pelaku illegal fishing).

Disamping, penindakan secara tegas juga harus memberikan upaya preventif kepada setiap pelaku yang akan dan yang telah melakukan penangkapan ikan diperairan agar memiliki rasa akan tunduk pada peraturan perundang- undagan yang berlaku. Edukasi dan penyuluhan berbagai aturan-aturan yang berlaku dan dampak yang akan diterima oleh pelaku dan lingkungan perairan jika tidak sesuai dengan aturan perundang-undangan yang berlaku. Penegakan pada sisi eksternal lebih diarahkan pada penguatan dan pembentukan kerjasama dengan pelaku-pelaku penangkapan ikan agar beroperasi. Hal ini, sesungguhnya sebagai penguatan dan penjalinan kerjasama dengan berbagai sektor 
baik bilateral, regional dan multilateral dengan internasional. Penegakan sisi eksternal ini menunjukkan eksistensi atas pengawasan penuh atas perairan nasional suatu negara dan siapapun yang ingin melakukan penangkapan diperairan suatu negara harus tunduk dan patuh terhadap segala peraturan dan perundang-undangan yang berlaku di negara tersebut. langkah ini bertujuan untuk mengoptimalkan kegiatan pengawasan dan pengendalian sumber daya kelautan dan perikanan termasuk upaya penanggulangan illegal fishing (Siahaan, 2017).

Berdasarkan analisis terhadap faktor-faktor dalam upaya penanggulangan terjadi illegal fishing dengan menggunakan matriks Strength, Weakness, Opportunity and Threat (SWOT) untuk menghasilkan peluang ekstrenal yang lebih baik. Beberapa strategi alternatif dalam menekan terjadinya serta upaya penanggulangan terjadinya tindak pidana illegal fishing yaitu sebgai berikut: a) Pengembangan system pengawasan ; meningkatkan pengawasan dengan meningkatkan patrol lebit intens dan dilakukan secara kontiniu; b) perbaikan sistem perijinan; dengan memperbaiki sistem prosedural kepengurusan ijin yang lebih baik dan transparan serta secara ketat; c) pemngembangan sistem peradilan perikanan yang lebih baik; adanya kesadaran yang tinggi dari pelaku-pelaku pengambil keputusan dalam mengadili sehingga memberikan hukuman dan sanksi yang tegas sesuai dengan peraturan perundangundangan yang berlaku; d) regionalisasi pengelolaan perikanan; sebagai upaya mempermudah pengawasan produk perikanan hasil tangkap yang lebih baik; e) pengembangan perikanan rakyat; sebagai upaya memonitoring kemampuan dan jangkauan nelayan tradisional dalam penangkapan hasil ikan; f) pengembangan industri perikanan terpadu; sebagai upaya mendekatkan atau mengorganisasi hasil produk secara efisien; g) eningkatan kerjasama dan internasional; hal ini untuk meningkatkan pengawasan secara bersama-sama; dan h) peningkatan edukasi tentang perundangundangan perikanan yang berlaku kepada masyarakat; sebagai kegiatan prevensif dalam rangka meningkatkan pemahaman akan peraturan perundang-undangan yang benar dan lebih baik.

\section{KESIMPULAN dan SARAN}

\section{a. Kesimpulan}

1. Bentuk illegal fishing yang terjadi di perairan Tanjungbalai yaitu penggunaan alat tangkap yang tidak sesuai undangundang (pukat tarik).

2. Upaya Polisi AIRUD dalam penanggunalan terjadinya illegal fishing di perairan Tanjungbalai yaitu upaya preventif dan refresif. Upaya preventif yang dimaksudkan yaitu meningkatkan intensitas sosialisasi peraturan perundangundangan kepada masyarakat, dan peningkatan patrol diperairan sesuai dengan jangkauan dari tugas Polisi AIRUD Tanjungbalai. Upaya refresif yaitu memerikan tindakan tegas terhadap pelaku illegal fishing sehingga memberikan efek jerah dan selalunjutnya memberikan arahan agar kelak bebas tidak mengulangi hal yang sama.

3. Hambatan Polisi AIRUD dalam penangulangan illegal fishing yaitu kurangnya personil, dan sumber daya manusia nelayan yang masih terbilang rendah, kelengkapan sarana dan fasilitas pendukung yang masih terbatas 
dalam meningkatkan patroli rutin dalam melaksanakan tugas pengawasan, perlindungan dan pengayoman masyarakan khsusunya nelayan di perairan.

\section{b. Saran}

Berdasarkan hasil penelitian, maka yang menjadi saran untuk upaya penanggulangan kejahatan illegal fishing yaitu:

a. Diperlukan kosistensi peningkatan terhadap aparat penegakan hukum baik secara preventif dan refresif terhadap pelaku-pelaku penangkapan ikan. Upaya preventif sebagai bagian dari pencegahan dari terjadinya tindakan illegal fishing dan upaya refresif sebagai bagian dari penindakan secara tegas tanpa pandang bulu kepada pelaku illegal fishing

b. Perlu dilakukan pembinaan atau penyuluhan (seperti sosialisasi dan pelatihan) kepada nelayan dalam rangka meningkatkan pemahaman nelayan terhadap pengelolaan perikanan yang berkelanjutan dan menghindari penggunaan alat-alat tangkap yang tidak sesuai dengan peraturan perundang- undagan yang berlaku.

c. Perlu dilakukan penambahan personil anggota dan kelengkapan pendukung dalam peningkatan operasional pengawasan dan pembinaan kepada nelayan agar melakukan penangkap ikan secara legal sesuai dengan peraturan perundang-undangan yang berlaku, karena penangkapan secara illegal sangat merugikan pada keberlanjutan sumberdaya perikanan yang tersedia di perairan dan sangat berdampak buruk pada sosial ekonomi nelayan.

\section{DAFTAR PUSTAKA}

1. Buku

Departemen Kelautan dan PerikananDKP. (2003). Konvensikonvensi Perikanan Internasional dan Inplementasinya di Indonesia. DKP RI. Jakarta.

Friedman, Lawrence M. (2013). Sistem Hukum: Presfektif Ilmu Sosial. Nusa Media. Bandung. hlm 6.

Koho, Zulkifli. (2015). Penegakan Hukum Tindak Pidana Illegal Fishing di Indonesia (Studi Kasus Penyalahgunaan Metode Tangkapan Dengan Bahan Peledak di Wilayah

Perairan Kabupaten Alor). Skripsi Ilmu Hukum Universitas Islam Negeri Sunan Kalijaga. Yogyakarta.

Mahmudah, Nunung. (2015). Illegal Fishing Pertanggungjawaban Pidana Korporasi di Wilayah Perairan Indonesia. Sinar Grafika. Jakarta.

Moh Nazir. (1988). Metode Penelitian. Ghalia Indonesia. Bogor . hlm 57.

Mukti Fajar dan Yulianto Ahmad. (2010). Dualisme Penelitian Hukum Normatif dan Empiris. Pustaka Pelajar. Yogyakarta. hlm 192.

Prof Dr. Sigit Riyanto, S.H., LL.M. (2014). Re- Interpretasi Kedaulatan Negara Dalam Hukum Internasional; Pidato Pengukuhan Jabatan Guru Besar Pada Fakultas Hukum Universitas Gadjah Mada. Fakultas Hukum Univeristas Gadjah Mada. Yogyakarta.

Salim HS dan Erlies. (2013). Penerapan Teori Hukum Pada Penelitian Tesis dan Disertasi. Rajawali. Jakarata. hlm 26.

Supriadi dan Alimudin. (2001). Hukum Perikanan di Indonesia. Sinar Grafika. Jakarta. hlm 429.

\section{Internet}

Ana Shofiana Syatiri, "Melawan Illegal Fishing, Penenggelaman 488 
Kapal, dan Dampak Positifnya", https://ekonomi.kompas.com /read/2018/10/16/032545926/mela wa n-illegal fishingpenenggelaman 488- kapal-dandampak-positifnya?page $=$ all, (diakses pada tanggal 21 Juli 2019, Pukul 22:00 Wib).

Pemerintah Tangjungbalai, 2015, Kondisi Geografis Tanjgjungbalai, BPS Tangjungbalai diakses https://tanjungbalaikota.go.id/kondi si-geogafis/ (diakses pada tanggal 21 Juli 2019, pukul 22:00 Wib)

Gunawan Sri Guntoro. (2012). TeoriTeori Hukum. Diakses dari: https://gunawansriguntoro. wordpress.com/2012/01/03/teoriteori- hukum/. (diakses pada tanggal 30 Maret 2019, Pukul 21.00 Wib).

Kompas, 2014, Menteri

Susi: Kerugian Akibat Illegal Fishing Rp 240 Triliun, diakses https://finance. detik.com/beritaekonomi-bisnis/d-2764211/menterisusi-kerugian-akibat-illegal-fishingrp- 240-triliun, (diakses pada tanggal 12 Juli 2019 Pukul 10 Wib).

Sistiyanto, Harjuno, 2018, IUU Fishing dan Ancaman Kedepannya Bagi Indonesia, Badan Riset dan SUmber Daya Manusia Kelautan dan Perikanan, diakses https://kkp.go.id/brsdm/artikel/5684 - $\quad$ iuu-fishing-dan-ancamankedepannya- bagi-indonesia, (diakses pada tanggal 22 Juli 2019, pukul 20:00 Wib).

Syahputra, Dodi., 2012, Tugas dan Fungsi Satuan Polri, https://dodisyahputra.wordpress.co m/ 2012/04/08/tugas-dan-fungsisatuan- polri/ (diakses pada tanggal 21 Juli 2019, Pukul 22:00 wib).

Tanty S. Reinhart Thamrin, "Penegakan Hukum Laut Terhadap Illegal Fishing", diakses dari: https://www.academia.edu/131201 62/Penegakan_Hukum_Laut_Terh adap_Illega _ Fishing, (diakses pada tanggal 22 Februari 2019, pukul 21.15 WIB).

3. Peraturan Perundang-Undangan

Kementerian Kelautan dan Perikanan RI, 2017, Peraturan Menteri Kelautan dan Perikanan Republik Indonesia Nomor 37/PERMEN$\mathrm{KP} / 2017$.

Kementerian Kelautan dan Perikanan RI, 2017, Peraturan Menteri Kelautan dan Perikanan Republik Indonesia Nomor 37/PERMENKP/2017

Peraturan Kepala Kepolisian Negara RI, 2010, Susunan Organisasi dan Tata Kerja Pada Tingkat Kepolisian Resor Dan Kepolisian Sektor

Presiden RI, 2009, Undang-Undang Republik Indonesia No. 45 Tahun 2009 Tentang Perikanan

Presiden Republik Indonesia, 2008, Undang- Undang Republik Indonesia Nomor 17 Tahun 2008 Tentang Pelayaran

Presiden Republik Indonesia, 1992, Undang- Undang Republik Indonesia Nomor 21 Tahun 1992 Tentang Pelayaran

Presiden Republik Indonesia, 2014, Undang- Undang Republik Indonesia Nomor 32 Tahun 2008 Tentang Kelutan

Undang-Undang Republik Indonesia, 2009, Undang-Undang No. 45 Tahun 2009 Tentang Perikanan

Undang Undang RI Nomor 5 tahun 1983 tentang Zona Ekonomi Ekslusif Indonesia

4. Artikel / Jurnal

Haryanto dan Joko Setiyono. (2017). Kebijakan Penenggelaman Kapal ASing Pelaku Illegal Fishing Oleh Pemerintah Indonesia Dalam Persfektif Hukum Pidana Internasional. Jurnal Law Reform, 13(1), 70-85.

Hehanussa dkk. (2018). Penegakan Hukum Illegal Fishing yang Dilakukan Oleh Kapal Asing di Wilayah Laut Indonesia Ditinjau dari Hukum Laut Internasional. eJurnal Komunitas Yustisia Universitas Pendidikan Ganesha 
Jurusan Ilmu Hukkum, hlm 1-13.

Lasabuda, Ridwan.

(2013).

Pembangunan Wilayah Pesisir dan

Lautan Dalam Presfektif Negara

Kepulauan Indonesia. Jurnal Ilmiah Platax, 1(2), 92-101.

Muhamad, S.V. (2012). "Illegal Fishing di Perairan Indonesia: Permasalahan dan Upaya Penanganannya Secara Bilateral di Kawasan. Politicia, 3(1), 59-85.
Siahaan, Jhon Mayer. (2017), Strategi Penanganan Illegal, Unregulated And Unreported Fishing (IuuFishing) Di Perairan Provinsi Riau Tahun 2014-2016, JOM FISIP, 4(1), 1-15.

Silalahi, R. (2019). KAJIAN HUKUM ATAS PERNYELESAIAN PERSELISIHAN HUBUNGAN INDUSTRIAL SECARA KONSILIASI. Jurnal Darma Agung, 27(2), 1000-1011. Retrieved from https://jurnal.darmaagung.ac.id/ind ex.php/jurnaluda/article/view/276

Widodo, J., 2003, Pemanfaatan dan Pengelolaan Sumberdaya Ikan di Perairan ZEE Indonesia dan Sekitarnya, Balai Riset Perikanan Laut, Jakarta: DKP RI. 